\title{
EFEITO DA ADUBAÇÃO NA PRODUTIVIDADE, QUALIDADE E SANIDADE DE BATATA CULTIVADA NO CENTRO-OESTE PARANAENSE
}

\section{EFFECT OF FERTILIZATION IN THE PRODUCTIVITY, QUALITY AND SANITY OF CULTIVATED POTATO IN THE MIDDLE-WEST OF PARANÁ}

\author{
Nicolau MALLMANN \\ Orientador(a): Prof. Dr. Luiz Antonio Correa LUCCHESI \\ (Departamento de Solos)
}

\begin{abstract}
RESUMO
A cultura da batata (Solanum tuberosum tuberosum L.) é para o Brasil, de grande relevância econômica, particularmente para os Estados do Paraná, Rio Grande do Sul, Minas Gerais, São Paulo e Santa Catarina, os quais abrigam $95 \%$ dos 182.000 ha atualmente cultivados em três safras anuais (águas, secas e inverno). Dentre estes, o Paraná, apesar de não apresentar as maiores produtividades médias, possui, ao lado do Rio Grande do Sul, uma das maiores áreas cultivadas (aproximadamente 40.700 ha, em 1999). Neste contexto, a região Centro-Oeste Paranaense (Campos de Guarapuava), tem se destacado pela qualidade e produtividade dos tubérculos produzidos para consumo direto, industrialização e multiplicação em seus 7.000 ha cultivados. Tal fato é creditado às características edafoclimáticas regionais favoráveis à cultura, aliadas a introdução de novos cultivares, materiais de propagação de origem controlada, épocas de plantio adequadas, controle de pragas e doenças, altas dosagens de adubações, irrigação suplementar, manejo do solo e a interação destes. No entanto, face aos crescentes custos de produção, problemas ambientais e potenciais ganhos de produtividade e qualidade, se faz necessária a geração de informações que melhor subsidiem as decisões técnicas tomadas, no intuito de se promover esta cultura, particularmente no que concerne ao manejo da fertilidade do solo. Neste particular, a adubação da batata vem sendo efetuada de maneira indiscriminada através da aplicação de 3 a 4 Mg.ha-1 das formulações 40-140-80 e 40-160-80 (g.kg-1 de N- $\left.\mathrm{P}_{2} \mathrm{O}_{5}-\mathrm{K}_{2} \mathrm{O}\right)$ não calibradas para as distintas situações encontradas, o que justifica a presente pesquisa. Desta forma, o objetivo deste trabalho foi avaliar o efeito de doses e do parcelamento de fertilizantes. Aplicação de doses de nitrogênio e de dois parcelamentos (Uréia), de doses de fósforo (Super fosfato triplo), de doses e fontes de potássio $\left(\mathrm{KCl}_{\mathrm{C}}\right.$ e $\mathrm{K}_{2} \mathrm{SO}_{4}$ ) sobre a produtividade e a qualidade de tubérculos, bem como sobre a sanidade da variedade Monalisa cultivadas na safra das águas (de novembro/98 a fevereiro/99). Para tanto foi conduzido um experimento sobre um Latossolo Bruno Distrófico, representativo da região, constituído por 18 tratamentos e quatro repetições, totalizando 72 parcelas de $15 \mathrm{~m}^{2}$, constituídas por 4 linhas de 14 tubérculos e $5 \mathrm{~m}$ de comprimento, espaçadas por $0,75 \mathrm{~m}$. Alcançou-se iguais produtividades e qualidade com dosagens de $\mathrm{P}_{2} \mathrm{O}_{5}$ inferiores às convencionalmente utilizadas pelos agricultores. O parcelamento da adubação nitrogenada favoreceu alguns dos parâmetros avaliados. A utilização de maiores doses de $\mathrm{K}_{2} \mathrm{O}$ e da fonte com enxofre favoreceu tanto a produtividade de tubérculos, quanto a qualidade e a sanidade da lavoura, o que poderia traduzirse em significativa contribuição à produção regional. Altas doses de $\mathrm{K}$ tenderam a aumentar a produtividade e reduzir os sintomas de sarna (Streptomyces scabies), canela preta (Erwinia carotovora carotovora), requeima (Phytophthora infestans), podridão seca (Fusarium solani) $\mathrm{e}$ pinta preta (Alternaria solani).

Palavras-chave: Batata; adubação; produtividade; qualidade; sanidade.
\end{abstract}

\section{ABSTRACT}

The potato (Solanum tuberosum tuberosum L.) is an economically important crop for Brazil, particularly for the states of Paraná, Rio Grande do Sul, Minas Gerais, São Paulo and Santa Catarina, which are the main potato producers, corresponding to $95 \%$ of the 182,000 ha cultivated with potato in the whole country. This total potato cultivated area consists of three main cropping seasons: Raining, Drought and Winter. Although not standing high in the average yield, the State of Paraná ranks equal to Rio Grande do Sul in terms of cultivated area, which is one of the largest in Brazil: near 40,700 ha, as of 1999 data. In this context, the Central-West region of Paraná, where Guarapuava Fields ("Campos de Guarapuava") area located has been striking for its outstanding potato tuber quality and yeld which are marketed as fresh, processed or as seed multiplication in its near 7,000 ha. Such high perfomance of Guarapuava's potato production is credited to an interaction of factors which can be identified as favorable climate and types, besides constant introduction of new cultivars, propagating material of known and certified origins, adequate planting seasons, integrated pest and disease management systems, appropriate fertilization and supplied irrigation, soil bed preparation, etc. Currently, however, the potato industry faces the challenge of an increasing production cost, environmental claims and potencial gains in yeld and quality. These factors require updated information which best support the decision makers toward promoting the potato crop. Among the most needed information stand those regarding soil and fertilization management. In this aspect, the fertilization applied to the potato crop has been basically and generally the 3 to $4 \mathrm{Mg}^{-h^{-1}}$ of the formulation 40-140-80 and 40-160-80 (g.kg-1 of $\mathrm{N}-\mathrm{P}_{2} \mathrm{O}_{5}-\mathrm{K}_{2} \mathrm{O}$ ). Facing this reality, which disregard the variation factors, the present research was carried out. Thus, the aim of this work was to evaluate the potato response on the tuber production and quality over fertilization doses and application time parcels, as well as the general health of the cultivar Monalisa, which is one of that covers over $3 / 4$ of the potato areas. The treatments were doses and two application times of Nitrogen (Urea), Phosphorous ("Supertriple") and doses and source of Potassium ( $\mathrm{KCl}$ and $\left.\mathrm{K}_{2} \mathrm{SO}_{4}\right)$. The studies were conducted in the rain season of 1998/1999 (November through February), with experiments installed in a very acidic brown oxisol (Latossolo Bruno distrófico) type of soil, which is representative for the potato cropping region. The experimental design was 18 treatments with four replicates, totaling 72 blocks of $15 \mathrm{~m}^{2}$, each composed of $5 \mathrm{~m}$ long rows, planted with 14 tubers, spacing $0.75 \mathrm{~m}$ from each other. The results showed an equivalent yeld and quality with reduced doses of $\mathrm{P}_{2} \mathrm{O}_{5}$ as compared to those usually applied by the potato producers. Timing for Nitrogen application favored some of the evalueted parameters. Increasing doses of $\mathrm{K}_{2} \mathrm{O}$ and origin os sulfur responded with improvement on either tuber yeld as well as quality. High K dosage lead to high yield and reduction of scab symptoms (Streptomyces scabies), black leg (Erwinia carotovora carotovora), late blight (Phytophthora infestans), dry rot (Fusarium solani) and early blight (Alternaria solani).

Key-words: Potato; fertilization; yield; quality; healthy. 